41 Kemmann, E, et al, American fournal of Obstetrics and Gynecology, 1977, $129,145$.

${ }^{42}$ Corbey, R S, Cruysberg, J R M, and Rolland, R, Obstetrics and Gynecology, 1977, 50, suppl No 1, p 69.

${ }^{43}$ Kleinberg, D L, et al, New England fournal of Medicine, 1977, 296, 589.

${ }^{44}$ Lamberts, S W J, et al, fournal of Clinical Endocrinology and Metabolism, $1977,44,180$

${ }^{45}$ Harries, J R, and Leven:, M B, Radiology, 1976, 120, 167.

46 Crompton, M R, and Layton, D D, Brain, 1961, 84, 85.

47 Almquist, S, et al, Acta Radiologica, 1964, 2, 179.

48 Waltz, T A, and Brownell, B, Fournal of Neurosurgery, 1966, 24, 901.

49 Hardy, J, fournal of Neurosurgery, 1971, 34, 582.
${ }^{50}$ Hardy, J, personal communication, 1977.

51 Perry-Keene, D A, Warne, G L, and Martin, F I R, Medical fournal of Australia, 1976, 2, 602.

${ }^{52}$ Corenblum, B, et al, Clinical Research, 1975, 23, abstract 614

${ }^{53}$ Vaidya, R, Aloorkar, S, and Sheth, A, Fertility and Sterility, 1977, 28, 363

${ }^{54}$ Lloyd, H M, Meares, J D, and Jacobi, J, Nature, 1975, 255, 497.

55 MacLeod, R M, and Lehmeyer, J E, Cancer Research, 1973, 33, 849.

56 Quadri, S K, and Meites, K H L J, Science, 1972, 176, 417.

57 Griffith, R W, Turkalj, I, and Braun, P, British fournal of Clinical Pharmacology, in press.

\title{
Interrelation of age, obesity, cigarette smoking, and blood pressure in hypertensive patients
}

\author{
D BALLANTYNE， B L DEVINE， R FIFE
}

British Medical fournal, 1978, 1, 880-881

\section{Summary and conclusions}

The relations between age, obesity, cigarette smoking, and blood pressure were investigated in 637 men and 835 women who had attended the Glasgow Blood Pressure Clinic with untreated hypertension. In contrast to results of population surveys of mainly normotensive people no relation was found between cigarette consumption and either systolic or diastolic blood pressure. Moreover, contrary to results of epidemiological studies a relation between adiposity and blood pressure was found in only male non-smokers. Thus the relations established for largely normotensive populations do not apply to hypertensive patients.

\section{Introduction}

In 1969 seven hypertension clinics at four hospitals were amalgamated to form the Glasgow Blood Pressure Clinic. New patients are extensively documented, and the data are stored on computer data files. ${ }^{1}$ To investigate the interrelation of age, obesity, cigarette smoking, and blood pressure we analysed the initial data on new, untreated patients who had attended the clinic since its inception.

\section{Patients and methods}

Data on 637 men and 835 women not receiving treatment when first seen at the clinic were analysed. Patients were considered to be hypertensive if their recumbent diastolic blood pressure, measured with a sphygmomanometer, was greater than $90 \mathrm{~mm} \mathrm{Hg}$ on at least two but usually three occasions before treatment. The means of these untreated values were used for analysis. During the initial clinic visit

Division of Clinical Medicine, Victoria Infirmary, Glasgow G42 9TY D BALLANTYNE, MD, MRCP, consultant physician

Division of Medicine, Glasgow Royal Infirmary, Glasgow B L DEVINE, MB, MRCP, medical registra R FIFE, MB, FRCP, consultant physician all patients were asked about their smoking habits, and smokers estimated the number of cigarettes they smoked daily. Cigarette smokers and non-smokers were analysed separately. To simplify interpretation of the results we excluded from the study patients who had stopped smoking cigarettes in the previous year and pipe and cigar smokers. The ponderal index, defined as (height in inches)/ (weight in $\mathrm{lb})^{\frac{1}{3}}$, was calculated for each patient.

Men and women were analysed separately. The mean $( \pm S D)$ age, number of cigarettes smoked daily, ponderal index, and recumbent systolic and diastolic blood pressures were calculated for each group. The interrelation of these variables was investigated by correlation analysis.

\section{Results}

Table I shows the mean age, cigarette consumption, ponderal index, and systolic and diastolic blood pressures for each of the four groups (male smokers and non-smokers; female smokers and nonsmokers). Age, ponderal index, and diastolic blood pressure were similar in all groups. Male smokers consumed more cigarettes each day than female smokers, and men had a lower mean systolic blood pressure than women.

\section{PARTIAL-CORRELATION ANALYSIS}

Male smokers-Partial-correlation analysis, controlled for age and ponderal index, indicated that in male smokers (table II) there was no significant correlation between the number of cigarettes smoked daily and either systolic or diastolic blood pressure. Similarly, there was no significant relation between ponderal index and blood pressure. The correlations between age and both systolic and diastolic blood pressures, however, were highly significant $(P<0.001)$.

Male non-smokers-As with the smokers, age was significantly related to both blood pressures $(\mathbf{P}<0.001)$. There were also significant relations between ponderal index and systolic and diastolic blood pressures $(\mathbf{P}<0.05$ and $\mathbf{P}<0.001$ respectively).

Female smokers-The relations found in female smokers were essentially similar to those found in male smokers but the correlations between age and blood pressures, although significant $(P<0.05)$, were weaker.

Female non-smokers-No relation was found between ponderal index and blood pressure, and only systolic blood pressure correlated significantly with age $(\mathrm{P}<0 \cdot 001)$.

\section{Discussion}

Acute experiments ${ }^{23}$ have shown that cigarette smoking causes a rise in blood pressure. In contrast, cross-sectional 
TABLE I-Mean $( \pm S D)$ age, daily cigarette consumption, ponderal index, and systolic and diastolic blood pressires in hypertensive men and women

\begin{tabular}{|c|c|c|c|c|c|c|c|c|}
\hline & & & \multirow{2}{*}{ No in group } & \multirow{2}{*}{ Age in years } & \multirow{2}{*}{$\begin{array}{l}\text { No of cigarettes } \\
\text { smoked daily }\end{array}$} & \multirow{2}{*}{ Ponderal index* } & \multicolumn{2}{|c|}{ Blood pressure $(\mathrm{mm} \mathrm{Hg})$} \\
\hline & & & & & & & Systolic & Diastolic \\
\hline \multicolumn{9}{|c|}{ Men } \\
\hline $\begin{array}{l}\text { Smokers .. } \\
\text { Non-smokers }\end{array}$ & $\because$ & 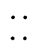 & $\begin{array}{l}353 \\
284\end{array}$ & $\begin{array}{l}48 \cdot 2 \pm 11 \cdot 4 \\
45 \cdot 0 \pm 12 \cdot 8\end{array}$ & $19 \cdot 3 \pm 9 \cdot 3$ & $\begin{array}{l}12 \cdot 3 \pm 0.6 \\
12 \cdot 1 \pm 0.6\end{array}$ & $\begin{array}{l}174 \cdot 3 \pm 24.9 \\
168 \cdot 6 \pm 23.9\end{array}$ & $\begin{array}{l}105.4 \pm 14.3 \\
103.9 \pm 14.8\end{array}$ \\
\hline \multicolumn{9}{|c|}{ Women } \\
\hline $\begin{array}{l}\text { Smokers } \\
\text { Non-smokers }\end{array}$ & $\begin{array}{l}\cdots \\
\cdots\end{array}$ & $\because$ & $\begin{array}{l}328 \\
507\end{array}$ & $\begin{array}{l}46 \cdot 2 \pm 12 \cdot 6 \\
48 \cdot 8 \pm 13 \cdot 9\end{array}$ & $15 \cdot 0 \pm 8 \cdot 3$ & $\begin{array}{l}12 \cdot 1 \pm 0 \cdot 8 \\
11 \cdot 8 \pm 0.8\end{array}$ & $\begin{array}{l}182 \cdot 2 \pm 5 \cdot 3 \\
181 \cdot 1 \pm 45 \cdot 3\end{array}$ & $\begin{array}{l}106 \cdot 5 \pm 14 \cdot 9 \\
106 \cdot 7 \pm 14 \cdot 7\end{array}$ \\
\hline
\end{tabular}

*(Height in inches)!(weight in $\mathrm{lb})^{\frac{1}{3}}$.

TABLE II-Correlation coefficients from partial-correlation analysis of blood pressure, age, ponderal index, ana daily cigarette consumption in hypertensive men and women

\begin{tabular}{|c|c|c|c|c|c|}
\hline & \multicolumn{2}{|c|}{ Men } & \multicolumn{2}{|c|}{ Women } & \multirow[b]{2}{*}{ Variables controlled } \\
\hline & $\begin{array}{c}\text { Systolic } \\
\text { blood pressure } \\
(\mathrm{mm} \mathrm{Hg})\end{array}$ & $\begin{array}{l}\text { Diastolic } \\
\text { blood pressure } \\
(\mathrm{mm} \mathrm{Hg})\end{array}$ & $\begin{array}{l}\text { Systolic } \\
\text { blood pressure } \\
(\mathrm{mm} \mathrm{Hg})\end{array}$ & $\begin{array}{l}\text { Diastolic } \\
\text { blood pressure } \\
(\mathrm{mm} \mathrm{Hg})\end{array}$ & \\
\hline \multicolumn{6}{|c|}{ Smokers } \\
\hline Cigarette consumption . & $\begin{array}{l}-0.04 \\
-0.09 \\
-0.04\end{array}$ & $\begin{array}{l}-0.05 \\
-0.08 \\
-0.05\end{array}$ & $\begin{array}{l}-0.04 \\
-0.07 \\
-0.04\end{array}$ & $\begin{array}{r}0.01 \\
-0.02 \\
0.01\end{array}$ & $\begin{array}{l}\text { Age } \\
\text { Ponderal index } \\
\text { Age and ponderal index }\end{array}$ \\
\hline Ponderal index .. & $\begin{array}{l}0.04 \\
0 \cdot 07 \\
0 \cdot 04\end{array}$ & $\begin{array}{l}-0.01 \\
-0.01 \\
-0.01\end{array}$ & $\begin{array}{l}0.03 \\
0.01 \\
0.03\end{array}$ & $\begin{array}{l}0.02 \\
0 \\
0.01\end{array}$ & $\begin{array}{l}\text { Age } \\
\text { Cigarette consumption } \\
\text { Age and cigarette consumption }\end{array}$ \\
\hline $\begin{array}{lll}\text { Age } & .\end{array}$ & $\begin{array}{l}0 \cdot 44^{* *} \\
0 \cdot 44^{* *} \\
0 \cdot 44^{* *}\end{array}$ & $\begin{array}{l}c \cdot 28^{* *} \\
0 \cdot 28^{* *} \\
0 \cdot 27^{* *}\end{array}$ & $\begin{array}{l}0 \cdot 15^{*} \\
0 \cdot 17^{*} \\
0 \cdot 16^{*}\end{array}$ & $\begin{array}{l}0 \cdot 17^{*} \\
0 \cdot 18^{*} \\
0 \cdot 18^{*}\end{array}$ & $\begin{array}{l}\text { Cigarette consumption } \\
\text { Ponderal index } \\
\text { Cigarette consumption and ponderal index }\end{array}$ \\
\hline \multicolumn{6}{|c|}{ Non-smokers } \\
\hline $\begin{array}{lll}\text { Ponderal index } & \ldots \\
\text { Age } & . & .\end{array}$ & $\begin{array}{l}-0 \cdot 16^{*} \\
0.38^{* *}\end{array}$ & $\begin{array}{r}-0.23^{* *} \\
0.21^{* *}\end{array}$ & $\begin{array}{l}-0.06 \\
0.29^{* *}\end{array}$ & $\begin{array}{l}0.01 \\
0.08\end{array}$ & $\begin{array}{l}\text { Age } \\
\text { Ponderal index }\end{array}$ \\
\hline
\end{tabular}

${ }^{*} \mathrm{P}<0.05 ;{ }^{* * \mathrm{P}}<0.001$.

studies have indicated that chronic cigarette smokers have lower blood pressures than non-smokers. ${ }^{4-8}$ Seltzer $^{4}$ showed that in people who stopped smoking the systolic blood pressure rose significantly. There is also evidence from population studies of a positive correlation between obesity and blood pressure. ${ }^{8-10}$ In a detailed study of a large male population, in which total body fat was measured by tritium dilution, Weinsier et al ${ }^{11}$ reported a correlation between body fat and blood pressure, which although of statistical significance was of only small magnitude. An inverse correlation between smoking and obesity has been found, ${ }^{12} 13$ and when this is taken into account in analyses some workers have found that the relation between cigarette smoking and blood pressure is removed. ${ }^{5}$ \& 8 Other studies, however, have shown that differences in relative body weight do not explain the significantly lower blood pressure in cigarette smokers. ${ }^{4}$ Almost all the people in these studies were normotensive. We, however, investigated the interrelation of age, obesity, cigarette smoking, and blood pressure in patients with documented hypertension.

In contrast to the results of the population studies we found no significant difference in mean systolic or diastolic blood pressure between smokers and non-smokers, whether men or women. This lack of effect of smoking on blood pressure was confirmed by partial-correlation analysis, in which the effects of age and degree of obesity were controlled. Although no relation was found, stopping smoking may result in a rise in blood pressure. There was no relation between ponderal index and either systolic or diastolic pressure in men and women smokers and women non-smokers. The isolated significant correlations between ponderal index and systolic and diastolic pressures in men non-smokers are difficult to explain; however, although these correlations were highly significant, they were clinically weak. From our data it therefore appears that weight reduction in hypertensive patients is unlikely to produce a significant fall in blood pressure. Nevertheless, at least one report has suggested that weight reduction does have a significant effect. ${ }^{14}$ Thus the alleged beneficial effect of weight reduction on blood pressure remains unresolved. A stronger correlation was found between age and blood pressure in men than women. In non-smoking women no relation was found between age and diastolic pressure, which was surprising.

Thus in this study of hypertensive patients we found no relation between smoking and blood pressure. Only in nonsmoking men was there a relation between obesity and blood pressure, and age and blood pressure appeared to be more strongly related in men than women.

We thank Dr J Robertson and the staff of the department of medical computing, Western Infirmary, Glasgow. We are also grateful to all medical and nursing staff who work at the Glasgow Blood Pressure Clinic.

Requests for reprints should be addressed to Dr D Ballantyne.

\section{References}

${ }^{1}$ Glasgow Blood Pressure Clinic, fournal of the Royal College of Physicians, $1972,7,87$.

2 Cellina, G U, et al, American Heart fournal, 1975, 89, 18.

3 Hines, E A, and Roth, G M, Proceedings of the Mayo Clinic, 1938, 13, 524.

${ }^{4}$ Seltzer, C C, American Heart fournal, 1974, 87, 558.

${ }^{5}$ Reid, D D, et al, Lancet, 1966, 1, 614.

${ }^{6}$ Karvonen, M, et al, Lancet, 1959, 1, 493.

${ }^{7}$ Gyntelberg, F, et al, Acta Medica Scandinavica, 1974, 195, 375.

${ }^{8}$ Reid, D D, et al, Lancet, 1967, 2, 1375.

${ }^{9}$ Epstein, F H, et al, American fournal of Epidemiology, 1965, 81, 307

${ }^{10}$ Kannel, W B, et al, Annals of Internal Medicine, 1967, 67, 48.

${ }^{11}$ Weinsier, R L, et al, American fournal of Medicine, 1976, 61, 815.

${ }^{12}$ Khosla, T, and Lowe, C R, British Medical fournal, 1971, 4, 10.

${ }^{13}$ Royal College of Physicians, Smoking and Health, p 102. London, Pitman Medical, 1971.

${ }^{14}$ Fletcher, B P, Quarterly fournal of Medicine, 1959, 23, 331.

(Accepted 26 fanuary 1978) 